\title{
Comparative analysis of depth distribution for seventeen large pelagic fish species captured in a longline fishery in the central-eastern Pacific Ocean
}

\author{
JIANGFENG ZHU ${ }^{1,2,3}$, LIUXIONG XU ${ }^{1,2}$, XIAOJIE DAI ${ }^{1,2}$, XINJUN CHEN $^{1,2}$ \\ and YONG CHEN 2,3 \\ ${ }^{1}$ College of Marine Sciences, Shanghai Ocean University, 999 Hucheng Huan Road, Shanghai 201306, China. \\ E-mail: xjdai@shou.edu.cn \\ ${ }^{2}$ The Key Laboratory of Sustainable Exploitation of Oceanic Fisheries Resources, Ministry of Education, 999 Hucheng \\ Huan Road, Shanghai 201306, China. \\ ${ }^{3}$ School of Marine Sciences, University of Maine, Orono, ME 04469, USA.
}

\begin{abstract}
SUMMARY: The objective of this study was to estimate depth distribution of pelagic species captured in a longline fishery and to evaluate the difference in depth distribution among species. We estimated depth distribution for 17 frequently captured species based on a Chinese longline fishing trip targeting bigeye tuna (Thunnus obesus) in the central-eastern Pacific Ocean in February-November 2006. The depth distributions of 13 bycatch species were significantly different from that of bigeye tuna. Although most of the bycatch species were found to be distributed in water depths shallower than bigeye tuna (i.e. increasing hook depths can decrease catch rates of these species), the rates of catch rates declined with increasing hook depths may be different. The depth distributions were found to be not significantly different between genders for 7 species. There was no significant correlation between fish sizes and capture depths. The information derived from this study can play an important role in reducing bycatch in pelagic tuna longline fisheries in the central-eastern Pacific Ocean.
\end{abstract}

Keywords: pelagic fish, tuna, bycatch, vertical distribution, longline, Pacific Ocean.

RESUMEN: ANÁLISIS COMPARATIVO DE LA DISTRIBUCIÓN EN PROFUNDIDAD DE DIECISIETE ESPECIES DE GRANDES PELÁGI-

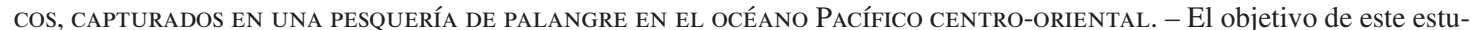
dio ha sido estimar la distribución en profundidad de especies pelágicas capturadas en una pesquería de palangre y evaluar la diferencia en la distribución en profundidad entre las especies. Se estimó la distribución en profundidad para 17 especies capturadas frecuentemente, sobre la base de los datos obtenidos en una marea de una pesquería de palangre china dirigida al patudo (Thunnus obesus) en el océano Pacífico centro-oriental, durante febrero-noviembre 2006. Las distribuciones en profundidad de 13 especies no objetivo de la pesquería fueron significativamente diferentes de la del patudo. Aunque la mayoría de estas 13 especies se encontraron a menor profundidad que el patudo, la medida en la que la captura acompañante disminuye puede ser diferente al situar los anzuelos a mayor profundidad. En 7 de las especies no se encontraron diferencias significativas entre sexos en relación a la distribución en profundidad. No hubo correlación significativa entre los tamaños de los peces y las profundidades de captura. La información derivada de este estudio puede jugar un rol importante en la reducción de la captura acompañante de pesquerías pelágicas con palangre dirigidas a captura de atunes en el océano Pacífico centro-oriental.

Palabras clave: peces pelágicos, atunes, bycatch, distribución vertical, palangre, océano Pacífico.

\section{INTRODUCTION}

Pelagic longline fishing gear is widely used in the open ocean to target tuna and billfish. The depth at which fish are captured can provide critical informa- tion for understanding the impacts of longline fisheries on targeted and bycatch species (Bigelow et al. 2006). Deploying longline hooks at appropriate depths can greatly improve catch of desired species, such as bigeye tuna (Thunnus obesus; Suzuki et al. 1977, Boggs 
1992) and billfishes (Boggs 1992), and reduce bycatch of protected species and untargeted species, such as sea turtles (Gilman et al. 2006, Beverly et al. 2009).

Several approaches can be used to obtain vertical distribution information for pelagic species. Electronic tags (e.g. acoustic, archival, and satellite) equipped with pressure sensors are an appropriate tool for observing vertical movements of pelagic fish in their habitat (Bach et al. 2003, Musyl et al. 2003, Schaefer et al. 2009, Walli et al. 2009, Stevens et al. 2010). Longlines equipped with time-depth recorders (TDRs) and hook timers provide information on the time and depth of capture for many pelagic species (Boggs 1992, Bach et al. 2003, Bigelow et al. 2006). One advantage of TDRs and hook timers, compared with electronic tagging studies, is that a large number of individuals of different sizes and species in different environmental conditions can be sampled (Bach et al. 2003).

Application of large numbers of TDRs on fishing vessels can be time-consuming and the cost prohibitive, and in practice it is not always feasible for commercial longliners (Bigelow et al. 2002). It has long been recognized that longline hook depth can be predicted using catenary algorithms (Yoshihara 1951, 1954, Suzuki et al. 1977). However, the direction and velocity of ocean currents and wind have important influences on catenary shape and hook depth (Ward and Myers 2006) and predicted depth may differ greatly from actual observed depth (e.g. by TDRs; Rice et al. 2007). Therefore, the catenary method has been frequently used for estimating hook depth in pelagic longline fisheries by using empirically derived correction factors (e.g. Hinton and Nakano 1996, Yano and Abe 1998, Bigelow et al. 2006, Ward and Myers 2006).

Much work has been done to investigate the vertical distribution of fish species of economical and/or ecological importance. Most of the work, however, focuses on single species, such as bigeye tuna (Bigelow et al. 2002, Bach et al. 2003), blue marlin (Makaira mazara; Luo et al. 2006), bigeye thresher shark (Alopias superciliosus; Nakano et al. 2003) and blue shark (Prionace glauca; Bigelow and Maunder 2007). Limited studies focus on the depth distributions of multiple species. For example, the depth distributions of 37 pelagic species caught in pelagic longlines in the Pacific Ocean were inferred by generalized linear mixed models (Ward and Myers 2005). To evaluate how vertical distributions of fish species may interact with longlines, a comparative study on differences in depth distributions among species is needed. This important topic has been rarely dealt with in previous studies.

In this study, we estimated hook depths of capture for 17 pelagic species captured during a Chinese longline fishing trip in the central-eastern Pacific Ocean. One hypothesis to be tested was whether there were significant differences in vertical distributions between target and bycatch species. For species with suitable sample sizes, gender- and size-specific differences in depth distributions were also evaluated. We were also
TABle 1. - Species captured in the longline observer trip in the central-eastern Pacific Ocean in February-November 2006. Species listed here are only those analyzed in this study.

\begin{tabular}{lllr}
\hline Category & Common name & Scientific name & Code \\
\hline Tuna & bigeye tuna & Thunnus obesus & BET \\
& yellowfin tuna & Thunnus albacares & YFT \\
& albacore & Thunnus alalunga & ALB \\
& skipjack & Katsuwonus pelamis & SKJ \\
Billfish & swordfish & Xiphias gladius & SWO \\
& blue marlin & Makaira mazara & BUM \\
Shark & blue shark & Prionace glauca & BSH \\
& bigeye thresher & Alopias superciliosus & BTH \\
& velvet dogfish & Zameus squamulosus & SSQ \\
& crocodile shark & Pseudocarcharias kamoharai & PSK \\
Other & pelagic stingray & Dasyatis violacea & PLS \\
& longnose lancetfish & Alepisaurus ferox & ALX \\
& bigscale pomfret & Taractichthys longipinnus & TAL \\
& sickle pomfret & Taractichthys steindachneri & TST \\
& escolar & Lepidocybium flavobrunneum & LEC \\
& black gemfish & Nesiarchus nasutus & NEN \\
& wahoo & Acanthocybium solandri & WAH \\
\hline
\end{tabular}

interested to test whether the results of these comparisons were robust to the methods used for correcting longline hook depth. The information derived from this study can improve our knowledge of the vertical distribution of pelagic species and can play an important role in developing methods for mitigating bycatch in pelagic tuna fisheries.

\section{MATERIALS AND METHODS}

\section{Data collection}

All data in this study were collected by an onboard fisheries observer during a commercial longline fishing trip in the central-eastern Pacific Ocean in FebruaryNovember 2006. This trip was conducted by a deep-set longline vessel (overall length $49 \mathrm{~m}$, beam $9 \mathrm{~m}$, depth $3.9 \mathrm{~m}, 495 \mathrm{GT}$ ) equipped to target bigeye tuna and freeze the catch. The longline gear consisted of a 120$130 \mathrm{~km}$ mainline, 40-50 m floatlines, and $46 \mathrm{~m}$ branchlines that were spaced $45-48 \mathrm{~m}$ apart. The number of hooks between floats (HBF) was 17 or 18 and "J" type tuna hooks were used. Setting began between 2:00 and 9:00 am and hauling began between 02:00 and 03:00 PM (local time). On average, 2500-3000 hooks were deployed for each set. Until now, all other China longline vessels and equipped gears operating in the central-eastern Pacific Ocean to target bigeye tuna, are similar to the one used in this study.

Set-specific latitude, longitude and gear configurations, including speed of vessel (8-14 knot) and speed of shooting mainline $\left(6-8 \mathrm{~m} \mathrm{~s}^{-1}\right.$, averaged over 3 observations per set at start of gear deployment, mid-point and close to end of deployment), HBF, length of mainline per basket (a "basket" encompassed the hooks between 2 successive floats, see $L$ in Eq. 1), and length of branchline and floatline were recorded. Fishes captured were randomly subsampled for biological measurements (including sex, length and weight) and the number of the hook that caught the fish was recorded. A total of 17 


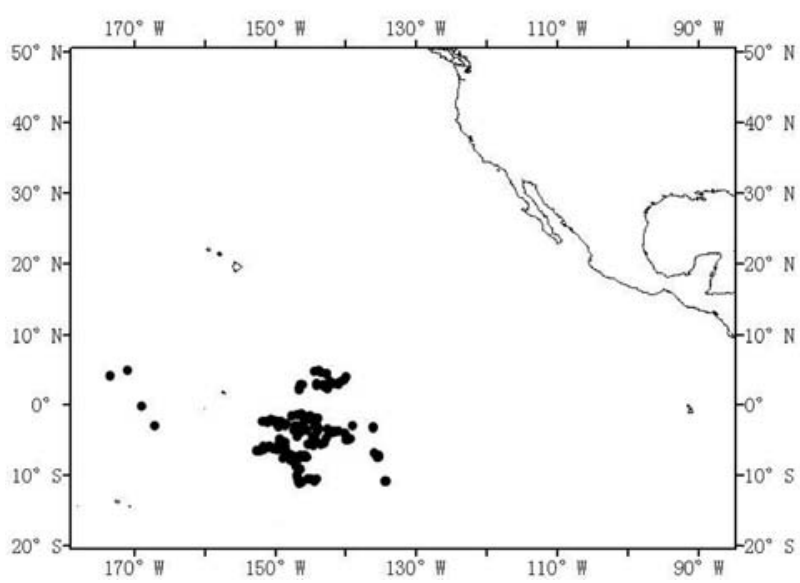

FIG. 1. - Set positions of the fishing trip for the Chinese longline fishery in the central-eastern Pacific Ocean in February-November 2006. Species sampled in these sets: BET (941), YFT (291), ALB (196), SKJ (32), SWO (70), BUM (35), BSH (118), BTH (55), SSQ (33), PSK (49), PLS (70), ALX (70), TAL (94), TST (37), LEC (115), NEN (64), WAH (73). See Table 1 for full species names. The number indicates sample size.

species (2343 individuals from 211 sets) were analyzed in this study (Table 1), where sample sizes were greater than $n=30$. Species other than the targeted bigeye tuna were all considered as bycatch species in this study. Set locations are shown in Figure 1.

\section{Hook depth estimation}

\section{Depth calculation}

Hook depth was calculated using the catenary method (Yoshihara 1951, 1954), which predicts the depth according to longline configuration using the following equation:

$D_{j}=h_{f}+h_{b}+\frac{L}{2}\left\{\left(1+\cot ^{2} \varphi^{\circ}\right)^{\frac{1}{2}}-\left[\left(1-\frac{2 j}{n+1}\right)^{2}+\cot ^{2} \varphi^{\circ}\right]^{\frac{1}{2}}\right\}$

where $D_{j}$ is the depth of $j$ th hook, $h_{f}$ and $h_{b}$ are the lengths of floatline and branchline, respectively (Fig. $2), L$ is the operational length of mainline in unit basket (calculated by the speed of shooting mainline multiplied by the time spent for deploying one unit of basket), $n$ is the number of branchlines in unit basket, and $\varphi^{\circ}$ is the angle between horizontal line and tangential line of the mainline at connecting points of the mainline and floatline. For each basket, the 2 hooks closest to the floats on the 2 ends are both numbered as the first hook, assuming that the branchlines were hung symmetrically. Because it was difficult to make direct measurements, $\varphi^{\circ}$ was solved by iteration of the sagging rate using the following formula (Yoshihara 1954):

$$
k=\cot \left(\varphi^{\circ}\right) \ln \left[\tan \left(45^{\circ}+\frac{\varphi^{\circ}}{2}\right)\right]
$$

float

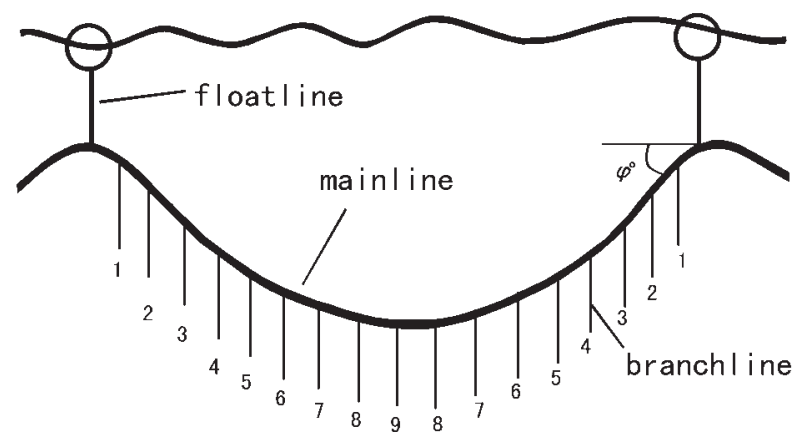

FIG. 2. - Configuration of unit basket of longline gear similar to the longline used by the Chinese tuna fishery in the central-eastern Pacific Ocean. The number in the illustration indicates the hook number, i.e. there are 17 hooks here in the unit basket.

where $k$ is the sagging ratio defined as the length of horizontal line divided by the length of mainline between unit baskets and estimated as the ratio of the speed of the mainline thrower to speed of vessel (Bigelow et al. 2006). In this study, speed of the line thrower and speed of vessel varied slightly during the trip. The range of $k$ was between 0.760 and 0.804 ; thus, by solving Eq. (2), $\varphi^{\circ}$ ranged from 60.0 to $55.5^{\circ}$.

\section{Within-set correction of hook depth}

The catenary method from Eq. (1) results in a single depth value for each longline hook. However, actual hook depth may vary both between and within sets (Bigelow et al. 2002). In this study, sagging ratio $k$ for each set was observed, so $\varphi^{\circ}$ value for each set was calculated using Eq. (2). Between-set variability of hook depth was therefore not subject to further consideration here.

Within-set variability of hook depth in longline gear has been reported in previous studies (Boggs 1992, Yano and Abe 1998, Bigelow et al. 2006, Bach et al. 2009). Yano and Abe (1998) found that for a given set of longline the hooks in deeper waters tended to have a larger variation in vertical distribution than hooks in shallower waters. Following Bigelow et al. (2002), we corrected hook depth $D_{j}$ using the following linear relationship developed by Yano and Abe (1998):

$$
\sigma\left(D_{j}\right)=8.73+4.4 j
$$

where $\sigma\left(D_{j}\right)$ is the standard deviation of hook depth $D_{j}$ and $j$ is the hook number as described above. For each $D_{j}$ calculated with Eq. (1), 1000 random samples of hook depths from normal distributions $N \sim\left(D_{j}, \sigma^{2}\left(D_{j}\right)\right)$ were generated and the mean of these values was regarded as the estimated depth of hook $j$.

\section{Correction of shoaling influence}

Actual hook depth is usually much shallower than that predicted using the catenary equation and is often referred to as shoaling (Bigelow et al. 2006, Bach 
et al. 2009). It is a common practice to express longline shoaling in terms of a percentage (Bach et al. 2009). This percentage-also called the correction factor-has been empirically used to adjust the hook depths calculated from the catenary method (Suzuki et al. 1977, Hinton and Nakano 1996). Correction factors may differ greatly in different oceanic areas due to different oceanographic conditions. Suzuki et al. (1977) estimated a shoaling of $15 \%$ (i.e. actual hook depth reaching $85 \%$ of predicted hook depth) to correct hook depth in the equatorial Pacific. This factor was adopted by Hinton and Nakano (1996). Bigelow et al. (2006) estimated a shoaling of $21 \%$ in the central North Pacific $\left(5-40^{\circ} \mathrm{N}, 127-174^{\circ} \mathrm{W}\right)$, based on the method of estimating sag ratios as in this study. Ward and Myers (2006) used a shoaling of $25 \%$ to correct hook depth of bigeye tuna in the tropical northern Pacific Ocean. The most recently published shoaling value was around $19 \%$, which was derived from the tropical southern Pacific Ocean (5-20 $0^{\circ}$ S $134-153^{\circ} \mathrm{W}$; Bach et al. 2009). Correction factors try to account for depth reduction by shoaling and for deep-set longline gears, and generally range between $15 \%$ and $25 \%$.

We used 3 methods to correct the predicted hook depth after within-set corrections. First, 3 constant correction factors, $15 \%, 20 \%$ and $25 \%$, were assumed to adjust the predicted depths, respectively. Second, setspecific random correction factors generated from a uniform distribution $U(0.15,0.25)$ were used. The hook depths in the same set were corrected using the same factor value, so 211 random numbers were used here. Third, hook-specific correction factors also generated from a uniform distribution $U(0.15,0.25)$ were used to adjust the predicted depths. Each predicted individual depth was assigned a single correction value, so 2343 random numbers were used.

\section{Statistical analysis}

The interquartile range (IQR) was used to show the difference in depth distribution among species. The IQR tends to be robust for outliers and extreme values, which are commonly observed in fisheries studies. The one-sample Kolmogorov-Smirnov goodness-of-fit test (one-sample K-S test) was used to test the normality of the depth distributions for each species. If they followed normal distributions, the two-sample $t$ test was used to test whether the mean depth of bigeye tuna differed significantly from the mean depth of bycatch species. We then chose the two-sample Wilcoxon rank-sum test (two-sample Wilcoxon test), a non-parametric method which needs no assumption of a certain distributional form, to examine whether the median depth of bigeye tuna differed significantly from the median depth of bycatch species. The two-sample Kolmogorov-Smirnov goodness-of-fit test (two-sample K-S test) was used to examine whether the depth distribution (the distribution function) of bigeye tuna differed from that of bycatch species (Venables and Ripley 1999). Simple
Bonferroni adjustment (target $P$ value $=0.05 /$ number of pairwise tests) was used to adjust the significance level for pairwise comparisons, which can reduce the risk of Type I error (Holm 1979). Differences in median depth and depth distribution between females and males were also evaluated by two-sample Wilcoxon test and twosample K-S test, respectively. Relationship between capture depth and fish size was examined by Pearson's correlation coefficient with $t$ test. The analysis was conducted for depth estimates derived from both constant and random shoaling correction factors.

After testing differences in depth between species, we employed divisive hierarchical cluster analysis with Euclidean distance to further identify the potential groups of these species. We divided the depth estimates of each of the 17 species into 4 depth ranges, 50-150 m, 151-200 m, 201-250 $\mathrm{m}$ and 251-300 m, and calculated the proportion of catch in number in each range. Thus, 4 variables with 17 observations were obtained for the cluster analysis. Depths derived from the constant (only using a shoaling factor of 20\%) and random shoaling factors were analyzed. All the statistical analysis was conducted in the S-PLUS program (Release7.0.6 for Windows).

\section{RESULTS}

\section{Depth range and distribution}

In addition to the targeted bigeye tuna, we estimated depth ranges for 16 bycatch species in the longline fishery, including 3 tuna species, 2 billfish species, 4 shark species and 7 other species (Table 1). Under constant shoaling assumptions, the minimum capture depth was estimated at 92,98 and $104 \mathrm{~m}$ for the shoaling assumption of $25 \%, 20 \%$ and $15 \%$, respectively, and the maximum capture depth was 253, 269 and 286 $\mathrm{m}$ for the 3 shoaling factors, respectively (Table 2). Bigeye tuna was captured at the deepest mean depth, and wahoo (Acanthocybium solandri) was captured at the shallowest mean depth. IQR plots for $20 \%$ shoaling suggested that depth distributions varied greatly among species (Fig. 3). Some species, such as blue marlin and blue shark, had similar median depths, but their depth ranges differed greatly. IQR plots for $15 \%$ and $20 \%$ shoaling factors showed the same trend.

\section{Comparison of depth between bycatch species and targeted bigeye tuna}

Because the one-sample K-S test indicated that capture depths of 8 of 17 species (BET, YFT, SKJ, BSH, BTH, ALX, LEC, WAH; See Table 1 for full species names) did not follow normal distribution $(P<0.05)$, we did not conduct $t$ tests for comparing the differences in mean capture depth between bigeye tuna and bycatch species. Differences in median depth and depth distribution between bycatch species and bigeye tuna, based on constant and random shoaling correc- 
TABLE 2. - Estimated depth ranges $(\mathrm{m})$ under constant shoaling assumptions for 17 pelagic species captured in the longline observer trip in the central-eastern Pacific Ocean in February-November 2006. The Max, Min and Mean represented maximum, minimum and mean depth, respectively. The lower case letter $\mathrm{n}$ indicates the sample size of the species. See Table 1 for full species names.

\begin{tabular}{|c|c|c|c|c|c|c|c|c|c|c|}
\hline Shoaling & & BET & YFT & ALB & $\mathrm{SKJ}$ & SWO & BUM & BSH & BTH & SSQ \\
\hline \multirow[t]{3}{*}{$25 \%$} & Max & 253 & 249 & 246 & 230 & 236 & 232 & 234 & 234 & 230 \\
\hline & Min & 92 & 92 & 92 & 92 & 93 & 92 & 92 & 95 & 95 \\
\hline & Mean & 193 & 160 & 152 & 132 & 157 & 142 & 150 & 177 & 172 \\
\hline \multirow[t]{3}{*}{$20 \%$} & Max & 269 & 265 & 262 & 245 & 252 & 247 & 250 & 250 & 245 \\
\hline & Min & 98 & 98 & 99 & 98 & 99 & 98 & 98 & 101 & 101 \\
\hline & Mean & 205 & 171 & 162 & 141 & 167 & 152 & 160 & 189 & 184 \\
\hline \multirow[t]{5}{*}{$15 \%$} & Max & 286 & 282 & 279 & 260 & 267 & 263 & 265 & 266 & 261 \\
\hline & Min & 104 & 104 & 105 & 104 & 105 & 104 & 104 & 108 & 108 \\
\hline & Mean & 218 & 182 & 173 & 150 & 178 & 161 & 170 & 200 & 195 \\
\hline & $\mathrm{n}$ & 941 & 291 & 196 & 32 & 70 & 35 & 118 & 55 & 33 \\
\hline & & PSK & PLS & ALX & TAL & $\mathrm{TST}$ & LEC & NEN & WAH & \\
\hline \multirow[t]{3}{*}{$25 \%$} & Max & 233 & 236 & 239 & 245 & 241 & 242 & 236 & 214 & \\
\hline & Min & 96 & 93 & 99 & 98 & 96 & 92 & 92 & 92 & \\
\hline & Mean & 161 & 139 & 179 & 182 & 180 & 167 & 157 & 117 & \\
\hline \multirow{2}{*}{$20 \%$} & Min & 102 & 99 & 105 & 105 & 103 & 98 & 99 & 98 & \\
\hline & Mean & 172 & 148 & 191 & 194 & 192 & 178 & 167 & 125 & \\
\hline \multirow[t]{4}{*}{$15 \%$} & Max & 253 & 267 & 271 & 278 & 273 & 274 & 268 & 241 & \\
\hline & Min & 109 & 105 & 112 & 111 & 109 & 104 & 105 & 104 & \\
\hline & Mean & 183 & 158 & 203 & 206 & 204 & 190 & 178 & 133 & \\
\hline & $\mathrm{n}$ & 49 & 70 & 70 & 94 & 37 & 115 & 64 & 73 & \\
\hline
\end{tabular}

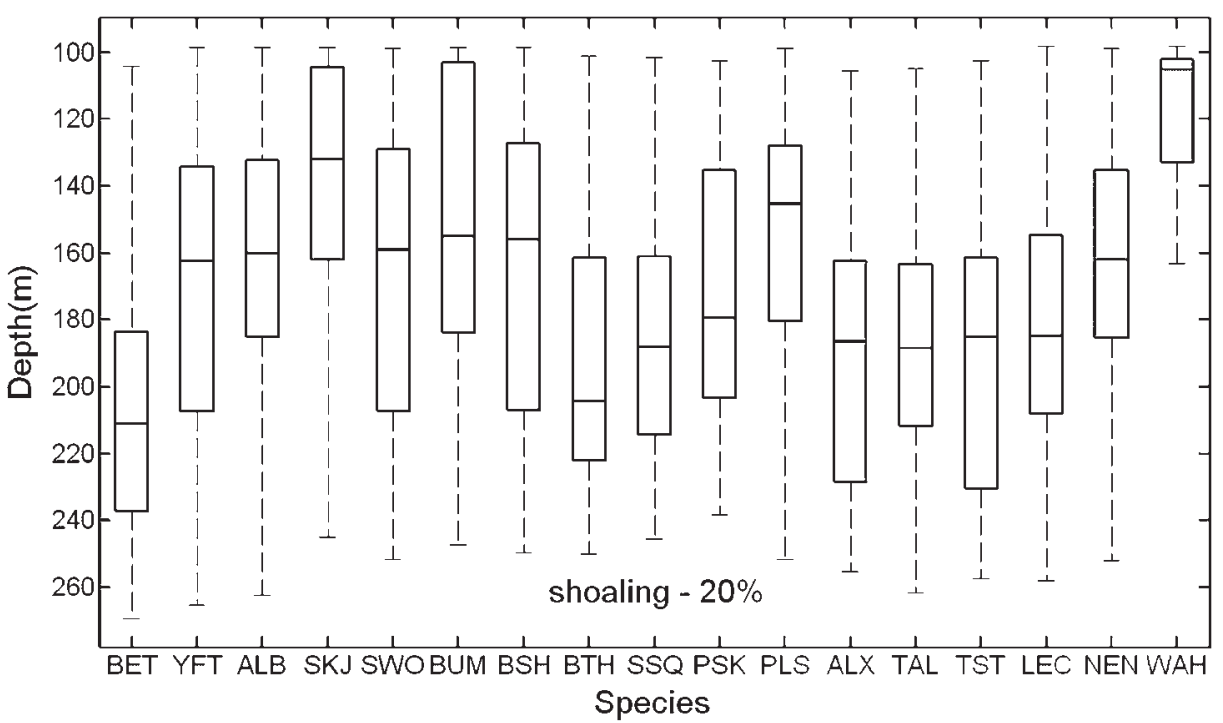

FIG. 3. - The box-plot of the estimated depth ranges under constant shoaling assumption (20\%) for 17 pelagic species captured in the longline observer trip in the central-eastern Pacific Ocean in February-November 2006 (the centre line is the median depth, the edges of the box are the

25th and 75th percentiles, respectively, and the whiskers extend to the most extreme data points). See Table 1 for full species names.

tion methods, were tested with $P$ values given in Table 3. The two-sample Wilcoxon test indicated that, except for bigeye thresher and sickle pomfret (Taractichthys steindachneri), the bycatch species had significantly different median depths from bigeye tuna (Table 3). This was consistent with the results derived by evaluating differences in the depth distribution between bycatch species and bigeye tuna. The two-sample K-S test suggested that, except for bigeye thresher, velvet dogfish (Zameus squamulosus) and sickle pomfret, each of the 13 bycatch species had significantly different depth distribution from bigeye tuna (Table 3 ). Cluster analysis showed dissimilarities among species regarding capture depth and species belonging to the same cluster tended to be captured in the same depth range (Fig. 4). Bigeye thresher and velvet dogfish showed more similarity to bigeye tuna in capture depth than the other 14 species (Fig. 4). A cluster tree based on constant and set-specific random correction factors showed almost the same grouping results.

\section{Differences in depth distribution between sexes and sizes}

The difference in capture depth between females and males was tested for 7 species (BET, YFT, SWO, 
TABLE 3. - The observed $P$ values for testing the difference in median depth and in depth distribution (estimated from constant and random shoaling assumptions) between bycatch species and bigeye tuna captured in the longline observer trip in the central-eastern Pacific Ocean in February-November 2006. The commonly used significance level of 0.05 was adjusted as 0.05/16=0.0031 (Simple Bonferroni adjustment for multiple comparisons) in determining whether the difference was significant. *: significant. See Table 1 for full species names.

\begin{tabular}{|c|c|c|c|c|c|c|}
\hline \multirow[b]{2}{*}{ Bycatch species } & \multicolumn{3}{|c|}{ two-sample Wilcoxon test for median depth } & \multicolumn{3}{|c|}{ two-sample K-S test for depth distribution } \\
\hline & $\begin{array}{l}\text { Constant } \\
\text { shoaling }\end{array}$ & $\begin{array}{l}\text { Set-specific } \\
\text { random shoaling }\end{array}$ & $\begin{array}{l}\text { Hook-specific } \\
\text { random shoaling }\end{array}$ & $\begin{array}{l}\text { Constant } \\
\text { shoaling }\end{array}$ & $\begin{array}{l}\text { Set-specific } \\
\text { random shoaling }\end{array}$ & $\begin{array}{l}\text { Hook-specific } \\
\text { random shoaling }\end{array}$ \\
\hline YFT & $*$ & $*$ & $*$ & $*$ & * & $*$ \\
\hline ALB & $*$ & $*$ & $*$ & $*$ & $*$ & $*$ \\
\hline SKJ & $*$ & $*$ & $*$ & $*$ & * & $*$ \\
\hline SWO & * & $*$ & $*$ & $*$ & * & $*$ \\
\hline BUM & $*$ & $*$ & $*$ & $*$ & $*$ & $*$ \\
\hline BSH & $*$ & $*$ & $*$ & $*$ & $*$ & $*$ \\
\hline BTH & 0.0152 & 0.0184 & 0.0075 & 0.0204 & 0.0678 & 0.0363 \\
\hline SSQ & 0.0040 & $*$ & 0.0035 & 0.0230 & 0.0078 & 0.0323 \\
\hline PSK & $*$ & $*$ & $*$ & $*$ & $*$ & $*$ \\
\hline PLS & $*$ & $*$ & $*$ & $*$ & $*$ & $*$ \\
\hline ALX & $*$ & 0.0071 & 0.0031 & $*$ & $*$ & $*$ \\
\hline TAL & $*$ & $*$ & $*$ & $*$ & $*$ & $*$ \\
\hline TST & 0.0440 & 0.2751 & 0.0244 & 0.0105 & 0.0313 & 0.0189 \\
\hline LEC & $*$ & $*$ & $*$ & $*$ & $*$ & $*$ \\
\hline NEN & $*$ & $*$ & $*$ & $*$ & $*$ & $*$ \\
\hline WAH & $*$ & $*$ & $*$ & $*$ & $*$ & $*$ \\
\hline
\end{tabular}

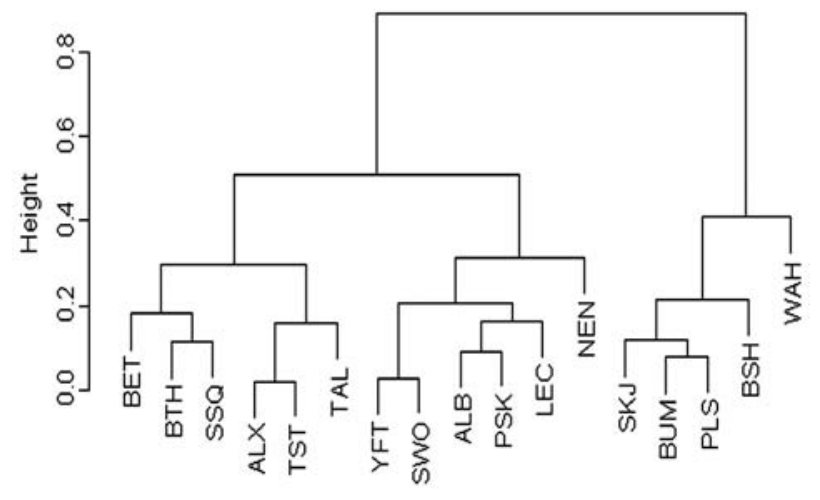

FIG. 4. - Clustering tree for 17 pelagic species captured in the longline observer trip in the central-eastern Pacific Ocean in FebruaryNovember 2006. The clustering was based on the Euclidean distance in the capture depth among different species. Capture depths were corrected by hook-specific shoaling factors from the uniform distribution $U(0.15,0.25)$. See Table 1 for full species names.

BSH, BTH, PSK, PLS). The two-sample Wilcoxon test indicated that median depths were not significantly different between females and males for all of the 7 species $($ target $P$ value $=0.0071 ; P>0.0071)$. Accordingly, the two-sample K-S test indicated that there were no significant differences in depth distribution between females and males (target $P$ value $=0.0071 ; P>0.0071)$. The results were not sensitive to the methods used for shoaling correction.

The relationship between capture depth and individual size (length) was examined using Pearson's correlation coefficients for all 17 species. Correlation coefficients were low and no significant correlations were found for any of the 17 species (target $P$ value $=0.0029 ; P>0.0029)$, indicating that smaller fishes were captured at almost the same depths as larger fishes. The results were also robust to the methods for correcting shoaling influences.

\section{DISCUSSION}

\section{Implication of differences/similarities in vertical distribution}

This study indicates that bigeye tuna showed different depth distributions to those of most bycatch species. Differences in capture depth among species are useful information for developing methods of mitigating bycatch by adjusting depths at which hooks are deployed in bigeye tuna fisheries.

Depth estimates and statistical tests indicated that 3 tuna species (YFT, ALB and SKJ), 2 billfish species (SWO and BUM), 2 shark species (BSH and PSK) and 6 other species (PLS, ALX, TAL, LEC, NEN and WAH) were captured at shallower depths than bigeye tuna. It is likely that setting longline hooks deeper can reduce catch rates of these bycatch species. This has been demonstrated for species such as wahoo, skipjack (Katsuwonus pelamis) and blue marlin. For example, eliminating shallow hooks from standard tuna longlines can significantly reduce wahoo catch rates (Beverly et al. 2009) and catch rates of skipjack and blue marlin decreased with the depth of longline hook being deployed (Nakano et al. 1997). Electronic tagging experiments also provided evidence for vertical habitat preferences of these pelagic species. Satellite telemetry tagging showed that blue sharks spent between $52 \%$ and $78 \%$ of their time at depths $<100 \mathrm{~m}$ and between $10 \%$ and $16 \%$ at depths $>300$ m off eastern Australia (Stevens et al. 2010).

Sickle pomfret and 2 shark species (bigeye thresher and velvet dogfish) were captured at about the same depth as bigeye tuna. Beverly et al. (2009) found that eliminating shallow hooks in the upper $100 \mathrm{~m}$ of the water column from standard tuna longlines could significantly increase catch rates of sickle pomfret. It was 
also reported that catch rate of bigeye thresher shark increased with the depth of hook deployed (Nakano et al. 1997). Satellite telemetry tagging has demonstrated that bigeye thresher shark spent least time in the surface layers and most time at $>300 \mathrm{~m}$ depth (Stevens et al. 2010). Therefore, adjusting longline gear in certain depth ranges can reduce catch rates of some species but increase catch rates of others.

Similarity or dissimilarity among species, derived from cluster analysis, should be considered in using differences in depth distribution between targeted and bycatch species to mitigate bycatch. Although most of the bycatch species were found to be distributed in shallower waters than bigeye tuna, the extent to which the bycatch decreased with increasing hook depths may be different. Catch rate of wahoo will probably decline more quickly than that of other species. Although capture depth distributions of sickle pomfret, bigeye thresher and velvet dogfish were not found to be significantly different from those of bigeye tuna, cluster analysis indicated that they belonged to different groups.

Because of depth limitation of longline gear, capture depths estimated from pelagic longline cannot represent the whole vertical habitat ranges for most species. For example, blue sharks spend between $35 \%$ and $58 \%$ of their time at depths of less than $50 \mathrm{~m}$ (Stevens et al. 2010), whereas most deep-set longline hooks are deployed beyond this depth. Tagging data showed that bigeye tuna can descend to depths beyond $450 \mathrm{~m}$ (Musyl et al. 2003, Schaefer et al. 2009) but the deepest hook depth was about $300 \mathrm{~m}$ in the Hawaii-based longline tuna sets (Bigelow et al. 2006). Therefore, the vertical ranges of these species are not fully covered by longline gears. In addition, speciesspecific availability and vulnerability to longline gear can also influence the capture depth distribution of target and bycatch species. Additional experimental fishing trials, covering a broader spatial-temporal range and a variety of gear types and deployment strategies, are needed to quantify the depth distributions of target and bycatch species.

Sexual segregation is a widespread behaviour in the animal kingdom and can arise within a species owing to sex differences in body size, activity, behaviour, nutritional requirements and/or habitat selection (Magurran and Macias Garcia 2000, Wearmouth and Sims 2008). Although sexual segregation for most pelagic species is of little interest, sexual segregation for sharks has attracted great interest because of the potential impacts on fisheries population dynamics and management (Mucientes et al. 2009). None of the 7 species examined in this study showed sexual segregation in vertical habitat, as there were no significant differences in vertical distributions between genders. This is probably due to the fairly limited spatial coverage of the study area. Highly migratory species may show sexual segregation on larger spatial scales.

\section{Factors influencing vertical distribution}

Many factors, including diel vertical movement, hook type and size, bait type and soak time, may influence the pelagic species' availability and vulnerability to capture by longline gear. Diel vertical movement might be the most important factor, and has been observed in the bigeye tuna (Holland et al. 1990a, Musyl et al. 2003), yellowfin tuna (Thunnus albacares; Holland et al. 1990a, Schaefer et al. 2009), skipjack (Yuen 1970, Schaefer et al. 2009), swordfish (Xiphias gladius; Carey and Robison 1981), blue marlin (Holland et al. 1990b), blue shark (Stevens et al. 2010) and bigeye thresher shark (Nakano et al. 2003, Stevens et al. 2010). Diel vertical movement range, however, may differ among species. Bigeye tuna is mainly distributed between 220 and $240 \mathrm{~m}$ during day time and between 70 and $90 \mathrm{~m}$ at night (Holland et al. 1990a). Yellowfin tuna, however, inhabits shallower water than bigeye tuna, and stays at an average daytime depth of $71.3 \mathrm{~m}$ and an average night-time depth of $47.3 \mathrm{~m}$ (Holland $e t$ al. 1990a). Blue marlin moves closer to the surface at night, which is consistent with the behaviour reported for skipjack (Yuen 1970), swordfish (Carey and Robison 1981) and bigeye thresher sharks (Nakano et al. 2003), but differs from that reported for the striped marlin (Tetrapturus audax; Holland et al. 1990b). However, vertical movement and distribution pattern for majority of pelagic species are still less understood. Collecting depth information covering the whole day time period is essential to improve our understanding of diel movement pattern and to develop appropriate fishing strategies for maintaining catch rates of target species and reducing catch rates of bycatch species at the same time.

\section{Factors influencing longline shoaling}

Environmental factors, such as current velocity, shear and wind, are probably the most significant factors accounting for the deviation between predicted hook depths derived using the catenary method and actual depths (Boggs 1992, Bigelow et al. 2006). We used constant and random shoaling factors to adjust predicted depth for pelagic species captured by longlines. The range of shoaling factors was chosen based on the results derived from previous studies (Hinton and Nakano 1996, Ward and Myers 2006).

Due to logistic constraints, shoaling factors have usually not been estimated for all hook positions between 2 consecutive floats. For instance, Bigelow et al. (2006) estimated shoaling percentages for deep-set longline gear by placing TDRs in the middle position on the mainline between 2 floats, a technique which was adopted by Bach et al. (2009). Having too few TDRs or not spacing them equally to monitor all hook positions may be a source of error for the estimation of longline shoaling factors. Moreover, a variety of gear configurations and deployment strategies may also 
cause errors when applying a shoaling factor derived from one gear configuration to another. For example, changing branchline and floatline length, HBF and/ or speed of shooting mainline can cause gear sinking into different water levels where environmental factors may vary. In the Hawaii-based commercial fishery, shoaling reached $\sim 50 \%$ for shallow swordfish sets and only $\sim 30 \%$ for deeper tuna sets (Bigelow et al. 2006). However, a large discrepancy in the estimates of shoaling between shallow and deep longline sets has been reported. The mean shoaling estimates on a shallow set were found to be $\sim 24 \%$ (Hanamoto 1974) and $\sim 11 \%$ (Nishi 1990) in the Pacific Ocean and Indian Ocean, respectively. Boggs (1992) estimated a shoaling factor of $46 \%$ for a deeper tuna set near the Hawaiian Islands.

Because we did not have TDRs placed on branchlines, hook depths estimated in this study should be considered to be biased to some extent. However, the comparative analysis we conducted with different shoaling factors indicates that the conclusions obtained in this study were robust to the methods used for correcting shoaling influences. This may result from the fact that the relative differences in capture depths among species were so large that they did not change too much after corrections by different shoaling factors. Such differences in capture depths among pelagic species are most likely to be determined by different vertical habitat preferences.

The method of estimating capture depth in this study assumed that all fishes were not caught when the longline was deployed or retrieved. In practice, some individuals can be captured during these 2 periods, but Boggs (1992) showed that most pelagic fish were caught while the longline gear was settled rather than while it was sinking or rising. Species mostly captured by shark hooks on floats were excluded in this study. It should be noted that a shark or large animal captured on these hooks could distort the shape and therefore the depth of longline. It might be better to exclude the baskets (even their adjacent baskets) with at least one big animal captured on shark hooks from the analysis. Unfortunately, we were not able to do this because of lack of this information.

\section{CONCLUSIONS}

Differences in depth distributions between targeted bigeye tuna and bycatch species associated with longline fisheries provide important information to mitigate bycatch. Setting deeper longline gear appears to reduce catch rates for most (13) of the 17 bycatch species in this study, including 2 shark species (blue shark and crocodile shark), whereas it increases catch rates of other (3) species, including 2 shark species (bigeye thresher and velvet dogfish).

Trade-offs need to be considered in order to adjust the depth of pelagic longline fishing gear in predicting catch rates among target species, protected species, and other ecologically and/or economically important species. Therefore, it is critical to identify fish species that play key roles in ecosystem dynamics and to investigate their vertical distribution for developing optimal operational depth ranges for pelagic longline fisheries. Investigating biological or ecological mechanisms for vertical habitat preferences by pelagic species can also improve our understanding of their availability and vulnerability to capture.

\section{ACKNOWLEDGEMENTS}

We would like to thank the onboard scientific observer Mr. W. Liu for collecting hte field data used in this study. This study was supported and funded by the China National Fishery Observer Programme, Shanghai Leading Academic Discipline Project (S30702) and National 863 project (2007AA092202). The Shanghai Ocean University College of Marine Sciences and the University of Maine School of Marine Sciences co-funded the senior author (J. Zhu) to complete this work at the University of Maine. The involvement of Y. Chen in this project is supported by the Shanghai Dongfang Scholar Programme. The authors would like to thank the editor and 2 anonymous reviewers for making comments that improved the manuscript.

\section{REFERENCES}

Bach P., Dagorn L., Bertrand A., Josse E., Misselis C. 2003. Acoustic telemetry versus monitored longline fishing for studying the vertical distribution of pelagic fish: bigeye tuna (Thunnus obesus) in French Polynesia. Fish. Res. 60: 281-292.

Bach P., Gaertner D., Menkes C., Romanov E., Travassos P. 2009. Effects of the gear deployment strategy and current shear on pelagic longline shoaling. Fish. Res. 95: 55-64.

Beverly S., Curran D., Musyl M., Molony B. 2009. Effects of eliminating shallow hooks from tuna longline sets on target and nontarget species in the Hawaii-based pelagic tuna fishery. Fish. Res. 96: 281-288.

Bigelow K.A., Maunder M.N. 2007. Does habitat or depth influence catch rates of pelatic species? Can. J. Fish. Aquat. Sci. 64: 1581-1594.

Bigelow K.A., Hampton J., Miyabe N. 2002. Application of a habitat-based model to estimate effective longline fishing effort and relative abundance of Pacific bigeye tuna (Thunnus obesus). Fish. Oceanogr. 11: 143-155.

Bigelow K., Musyl M.K., Poisson F., Kleiber P. 2006. Pelagic longline gear depth and shoaling. Fish. Res. 77: 173-183.

Boggs C.H. 1992. Depth, capture time, and hooked longevity of longline-caught pelagic fish: timing bites of fish with chips. Fish. Bull. 90: 642-658.

Carey F.G., Robison B.H. 1981. Daily patterns in the activities of swordfish, Xiphias gladius, observed by acoustic telemetry. Fish. Bull. 79: 277-292.

Gilman E., Zollett E., Beverly S., Nakano H., Davis K., Shiode D., Dalzell P., Kinan I. 2006. Reducing sea turtle by-catch in pelagic longline fisheries. Fish Fish. 7: 2-23.

Hanamoto E. 1974. Fishery oceanography of bigeye tuna. I. Depth of capture by tuna longline gear in the eastern tropical Pacific Ocean. La Mer 13: 58-71.

Hinton M.G., Nakano H. 1996. Standardizing catch and effort statistics using physiological, ecological, or behavioral constraints and environmental data, with an application to blue marlin (Makaira nigricans) catch and effort data from Japanese longline fisheries in the Pacific. Inter-Amer. Trop. Tuna Comm. Bull. 21: 169-200.

Holland K.N., Brill R.W., Chang R.K.C. 1990a. Horizontal and vertical movements of tunas (Thunnus spp.) associated with fish 
aggregating devices. Fish. Bull. 88: 493-507.

Holland K.N., Brill R.W., Chang R.K.C. 1990b. Horizontal and vertical movements of Pacific blue marlin captured and released using sportfishing gear. Fish. Bull. 88: 397-402.

Holm S. 1979. A simple sequential rejective multiple test procedure. Scand. J. Stat. 6: 65-70.

Luo J., Prince E.D., Goodyear C.P., Luckhurst B.E., Serafy J.E. 2006. Vertical habitat utilization by large pelagic animals: a quantitative framework and numerical method for use with popup satellite tag data. Fish. Oceanogr. 15: 208-229.

Magurran A.E., Macias Garcia C. 2000. Sex differences in behaviour as an indirect consequence of mating system. J. Fish. Biol. 57: 839-857

Mucientes G.R., Queiroz N., Sousa L.L., Tarroso P., Sims D.W. 2009. Sexual segregation of pelagic sharks and the potential threat from fisheries. Biol. Lett. 5: 156-159

Musyl M.K., Brill R.W., Boggs C.H., Curran D.S., Kazama T.K., Seki M.P. 2003. Vertical movements of bigeye tuna (Thunnus obesus) associated with islands, buoys, and seamounts near the main Hawaiian Islands from archival tagging data. Fish. Oceanogr. 12: 152-169

Nakano H., Okazaki M., Okamoto H. 1997. Analysis of catch depth by species for tuna longline fishery based on catch by branch lines. Bull. Nat. Res. Inst. Far Seas Fish. 34: 43-62.

Nakano H., Matsunaga H., Okamoto H., Okazaki M. 2003. Acoustic tracking of bigeye thresher shark Alopias superciliosus in the eastern Pacific Ocean. Mar. Ecol. Prog. Ser. 265: 255-261.

Nishi T. 1990. The hourly variations of the depth of hooks and the hooking depth of yellowfin tuna (Thunnus albacares), and bigeye tuna (Thunnus obesus), of tuna longline in the eastern region of the Indian Ocean. Mem. Fac. Fish. Kagoshima Univ. 39: 81-98.

Rice P.H., Goodyear C.P., Prince E.D., Snodgrass D., Serafy. J.E. 2007. Estimation of hook depth during near surface pelagic longline fishing using catenary geometry: Theory versus practice. North Am. J. Fish. Manage. 27: 1148-1167.

Schaefer K.M., Fuller D.W., Block B.A. 2009. Vertical movements and habitat utilization of skipjack (Katsuwonus pelamis), yellowfin (Thunnus albacares), and bigeye (Thunnus obesus) tunas in the equatorial eastern Pacific Ocean, ascertained through archival tag data. In: Nielsen J.L., Arrizabalaga H., Fragoso N., Hobday A., Lutcavage M., Sibert J. (eds.), Reviews: Methods and Technologies in Fish Biology and Fisheries, Volume 9: Tagging and Tracking of Marine Animals with Electronic Devices. Springer, Netherlands, pp. 121-144.

Stevens J.D., Bradford R.W., West G.J. 2010. Satellite tagging of blue sharks (Prionace glauca) and other pelagic sharks off eastern Australia: depth behaviour, temperature experience and movements. Mar. Biol. 157: 575-591.

Suzuki Z., Warashina Y., Kishida M. 1977. The comparison of catches by regular and deep tuna longline gears in the western and central equatorial Pacific. Bull. Far Seas Fish. Res. Lab. 15: $51-89$

Venables W.N., Ripley B.D. 1999. Modern Applied Statistics with $S$-PLUS. 3rd edn. Springer, New York, $501 \mathrm{pp}$.

Walli A., Teo S.L.H., Boustany A., Farwell C.J., Williams T., Dewar H., Prince E., Block B.A. 2009. Seasonal movements, aggregations and diving behavior of Atlantic bluefin tuna (Thunnus thynnus) revealed with archival tags. PLoS ONE 4: 1-18.

Ward P., Myers R.A. 2005. Inferring the depth distribution of catchability for pelagic fishes and correcting for variations in the depth of longline fishing gear. Can. J. Fish. Aquat. Sci. 62: 1130-1142.

Ward P., Myers R.A. 2006. Do habitat models accurately predict the depth distribution of pelagic fishes? Fish. Oceanogr. 15: 60-66.

Wearmouth V.J., Sims D.W. 2008. Sexual segregation of marine fish, reptiles, birds and mammals: behaviour patterns, mechanisms and conservation implications. Adv. Mar. Biol. 54: $107-170$

Yano K., Abe O. 1998. Depth measurements of tuna longline by using time-depth recorder. Nippon Suisan Gakkaishi 64: 178-188.

Yoshihara T. 1951. Distribution of fishes caught by the longline - II. Vertical distribution. Bull. Jap. Soc. Sci. Fish. 16: 370-374.

Yoshihara T. 1954. Distribution of catch of tuna longline - IV. On the relation between $\mathrm{k}$ and phi with a table and diagram. Bull. Jap. Soc. Sci. Fish. 19: 1012-1014.

Yuen H.S.H. 1970. Behavior of skipjack tuna, Katsuwonus pelamis, as determined by tracking with ultrasonic devices. J. Fish. Res. Board. Can. 27: 2071-2079.

Scient. ed.: G. Pequeño.

Received March 14, 2011. Accepted July 7, 2011.

Published online December 16, 2011. 